Relations industrielles

Industrial Relations

\title{
Hardy Green, On Strike at Hormel: The Struggle for a Democratic Labor Movement
}

\section{Norman Lederer}

Volume 46, numéro 3, 1991

URI : https://id.erudit.org/iderudit/050703ar

DOI : https://doi.org/10.7202/050703ar

Aller au sommaire du numéro

Éditeur(s)

Département des relations industrielles de l'Université Laval

ISSN

0034-379X (imprimé)

1703-8138 (numérique)

Découvrir la revue

Citer ce compte rendu

Lederer, N. (1991). Compte rendu de [Hardy Green, On Strike at Hormel: The Struggle for a Democratic Labor Movement]. Relations industrielles / Industrial Relations, 46(3), 664-666. https://doi.org/10.7202/050703ar

Tous droits réservés (C) Département des relations industrielles de l'Université Laval, 1991
Ce document est protégé par la loi sur le droit d'auteur. L'utilisation des services d'Érudit (y compris la reproduction) est assujettie à sa politique d'utilisation que vous pouvez consulter en ligne.

https://apropos.erudit.org/fr/usagers/politique-dutilisation/ 
with arbitration and he refers approvingly to experience in Australia and New Zealand. However, all systems of wage arbitration that exist are concerned with the wages that workers receive, and not with making the labour market more efficient. In Australia, for example, criteria such as a living wage or a wage to support a family of four have often been used. In addition, the author appears to be oblivious to the political, economic, and social complexities of Canada. With the federal government having jurisdiction over only 10 percent of the labour force and with the provinces having jurisdiction over the other 90 percent, how could we ever get agreement of the creation of a national system of arbitration - which is the type implicit in this book - with agreed upon criteria and rules of procedure? Past experience in trying to get agreement among federal and provincial governments about wage restraint programs suggests that they would never agree to a national system of arbitration.

With respect to the distribution of income, is there any reason to believe that we would have a fairer distribution of income with arbitration of collective bargaining disputes than we have under our present system. I submit that there is nothing in logic to suggest that we would. Welfare payments would probably continue to be well below the poverty level as is the case at present in all provinces, sales tax variations across the country would continue, and provincial income taxes could hardly be expected to change.

I agree with J.T. Dunlop that we should nourish the things that collective bargaining does well - things that are mentioned only in passing in the book under review - and not impose on it problems for which it was not intended. But that is precisely what this book does. However, we need not worry about policy makers implementing an arbitration service along the lines suggested since the author has not made a convincing and realistic case for his policy alternative - something that he rightly insists that reviewers take into account in assessing his book.

Alton CRAIG

University of Ottawa

On Strike at Hormel: The Struggle for a Democratic Labor Movement, by Hardy Green, Philadelphia, Temple University Press, 1990, xv, 368 p., index, ISBN 0-87722-635-0

The fight on the part of Local P-9 of the United Food and Commercial Workers (UFCW) in Austin Minnesota against wage and benefit concessions sought by the Geo. A. Hormel Company ended in utter failure. The unfolding human strategy that occurred between 1984 and 1986 in a formerly closeknit "All American" small city in the heartland of America resulted in the destruction of the livelihoods of hundreds of families headed by rank and file unionists. When the dust had settled, Local P-9 had been placed into trusteeship by the International Union; the company got its concessions and huge profits to boot; and another nail had been pounded into the coffin of organized labor in the United States.

The Hormel strike exhibited many of the underlying causes for the malaise of the contemporary American labor movement, at least in the United States. The walkout was a reaction against the effort on the part of the company to break the "social contract" which had existed between labor and management at Hormel for generations. Relations between the organized labor force and management at Hormel degenerated so quickly in the course of the strike that it was difficult to believe that until the $1970 \mathrm{~s}$, at least, working at Hormel represented the attainment of the bluecollar dream for most workers at the Austin plant. The company dominated Austin as its leading employer and rate payer, but Hormel was for many years a 
benevolent giant in the community. Like the Old Dope Peddler in Tom Lehrer's song, Hormel was "doing well by doing good". Out of the cauldron of strife and bitterness brought to a boil during the brutal labor-management wars of the Great Depression, determined rank and file leaders had forged a union which not only brought about collective bargaining at Hormel but also managed to establish itself on a basis of near-parity with the plant management. The union, founded by former members of the Industrial Workers of the World and other militants, became part of the United Packinghouse Workers of America in 1943.

Times were good for Hormel and its unionized employees during and after World War II. Millions of cans of Spam were processed in Austin and were shipped out to feed the Allied armies and a good deal of the world's population as well. To work at Hormel was now to realize high wages and excellent benefits, while in the community the Hormel Foundation bestowed funds on worthwhile local projects. Jobs at Hormel were coveted; handed down from father to son and taken for granted as worklife sinecures. In later years, Hormel workers looked back at the 1940s and 1950s as "golden years" of prosperity; which in a relative sense they certainly were.

The honeymoon between the workers and the company at Hormel began to sour in the 1960s. The "Big Four"' of meat packing, of which Hormel was one, came under intense attack from low cost, non-union meat processing firms, of which Iowa Beef Processors was the most profitable. These companies, located in rural areas near the source of supply, did away with the need for supermarkets to employ high wage butchers and meat cutters through prepackaging meat already cut into desired chops, steaks, etc. ready for the table. The old line meat packers, unused to competition, fell prey to conglomerates who took them over and in many instances milked their assets until the companies either folded or drastically reduced their operations.

The Hormel company, no longer headed by the reluctantly benevolent patriarch who had founded the concern, decided to play tough. The "Working Agreement" of guaranteed employment, a year's notice of major company change, etc., was gradually chipped away. In its place, quarterly profits became the be-all and end-all of corporate existence, with any idea of long range stability thrown into the trash heap. The fortunes of the union waned as the short term profits of the corporation waxed. The United Packinghouse Workers merged with the UFCW and became a division of a conglomerate union headed at the International level by a former retail clerk. The once proud meat packers no longer felt in charge of their own destiny in a union in which they played a now distinctly subordinate role.

The spark that ignited the Hormel tinderbox in December, 1986, was the company's effort to become more competitive through the reduction of worker wages and benefits. Pointing out that in the early 1980 s a wave of plant closings plagued the meat industry, Hormel executives predicted the same for the Austin plant, even given the almost brand new facilities in being. The UFCW International supported the concessions, believing that unless relief was granted to the company, it would move to a non-union location. The UFCW employed a strategy whereby concessions would be granted to companies in the area of wages and benefits while at the same time unorganized companies would be organized. Once the industry as a whole was organized, the UFCW would put into practice a national drive to raise all wages and restore benefits. The strategy was foredoomed to failure and in fact may not ever have been really taken seriously by the International.

The men and women of P-9 struck Hormel and immediately ran up against implacable company opposition and that of their International as well. To further their cause, P-9 hired the labor-oriented public relations firm of Corporate Campaigns Inc., headed by the colorful 
and controversial Ray Rogers. Local P-9 President Jim Guyette worked closely with Rogers in the effort to not only win the strike at the plant gates but also on the stage of national public opinion.

Hardy Green, a consultant for Corporate Campaigns Inc., held a unique position within the strike apparatus, with a vantage point from which he could observe the internal workings of the campaign, as well as its public manifestations. His narrative of the strike, therefore, although certainly not objective, is a remarkably valuable record of the struggle. His account provides an almost day-by-day rendering of the manner in which determined grass-roots leaders, backed up by equally redoubtable rank and filers, held out against overwhelming odds until the company, the International union and the local and state police apparatus compelled them to throw in the towel.

Green's narrative deals with a union cause that, like so many others of the 1980s, seems to have been almost foredoomed to failure. The struggles of men and women desperately trying to maintain human dignity against insurmountable odds, takes on, in Green's telling, an almost Homeric quality. To be sure no one was completely without $\sin$ in this struggle. But certainly most nearly blameless were the Hormel workers who gave their economic all, only to be permanently replaced by scabs and those of their brethren who crossed the line. Reading Green's gripping account at times reduces one to tears.

Norman LEDERER

Thaddeus Stevens State School of Technology

Labor-Management Cooperation, New Partnerships or Going in Circles?, by William N. Cooke, Kalamazoo, Michigan, W.E. Upjohn Institute, 1990, 198 p., ISBN 0-88099-100-3

Cooke has conducted a much needed study of cooperative labor-management programs in unionized manufacturing companies. The study is particularly useful for its theoretical framework and survey of union and management experience with cooperative programs.

The theoretical framework introduced concepts which were used in interpreting survey results. The theoretical framework was mainly concerned with power sharing. Both unions and management must give up "relative power options" which heighten conflict in order to achieve benefits of cooperative efforts.

The survey is based on a random sample of unionized manufacturing companies in the United States. Information comes from 194 companies and most of these companies were represented by questionnaire responses from the plant manager, the union president and a headquarters executive.

The findings were quite clear for a study of this size. Following the work of Kochan, Cooke divided the parent corporations into three groups according to union strategy, "unionavoidance", "cooperation", and "mixed". The study found that most of plants, whose parent corporation, favored cooperation with unions, had formalized labor-management programs and few of the union avoidance corporations had cooperative programs in their plants. Thus the occurrence of formal cooperative programs in plants was greatly influenced by corporate strategy.

The plant level programs were classified as team based (quality circles, work teams, QWL/EI, gainsharing, and ESOPs) and committee based (labor-management and productivity committees). Success of these programs was measured in terms of improvement in quality, 